\title{
Comparison of Anaerobic Degradation Processes for Bioenergy Generation from Liquid Fraction of Pressed Solid Waste
}

ARTICLE in WASTE AND BIOMASS VALORIZATION · MAY 2015

DOI: $10.1007 /$ s12649-015-9379-y

DOWNLOADS

16

8 AUTHORS, INCLUDING:

Nándor Nemestóthy

University of Pannonia, Veszprém

48 PUBLICATIONS 380 CITATIONS

SEE PROFILE

Péter Bakonyi

University of Pannonia, Veszprém

26 PUBLICATIONS 98 CITATIONS

SEE PROFILE
Katalin Bélafi-Bakó

University of Pannonia, Veszprém

90 PUBLICATIONS 920 CITATIONS

SEE PROFILE

Robert Kurdi

University of Pannonia, Veszprém

19 PUBLICATIONS 171 CITATIONS

SEE PROFILE 

9 0

\section{Comparison of anaerobic degradation processes for bioenergy generation from liquid fraction of pressed solid waste}

Rózsenberszki T ${ }^{\mathrm{a}}$, Koók L ${ }^{\mathrm{a}}$, Hutvágner $\mathrm{D}^{\mathrm{a}}$, Nemestóthy $\mathrm{N}^{\mathrm{a}}$, Bélafi-Bakó $\mathrm{K}^{\mathrm{a}}$, Bakonyi $\mathrm{P}^{\mathrm{a},{ }^{*}}$, Kurdi

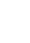
$\mathrm{R}^{\mathrm{b}}$, Sarkady $\mathrm{A}^{\mathrm{b}}$

${ }^{a}$ : Research Institute on Bioengineering, Membrane Technology and Energetics University of Pannonia

Egyetem ut 10, 8200 Veszprém, Hungary

${ }^{\mathrm{b}}$ : Institute of Environmental Engineering University of Pannonia Egyetem ut 10, 8200 Veszprém, Hungary

"Corresponding Author: P. Bakonyi Tel: +3688624385 Fax: +3688624292

E-mail: bakonyip@almos.uni-pannon.hu 


\section{Abstract}

2

3 A novel substrate (obtained from biofraction of municipal solid waste by pressing and

4 called LPW) rich in organic substances was used in three anaerobic degradation processes

5 (biogas, biohydrogen fermentation and microbial fuels cells) to comparatively assess their

6 feasibility for energy recovery. It has turned out that all the processes have successfully degraded

7 that substrate and produced energy carriers (methane and hydrogen) as well as bioelectricity. The

8 maximum energy yields $\left(\mathrm{J} \mathrm{g}^{-1} \mathrm{COD}_{\text {removed }} \mathrm{d}^{-1}\right)$ and associated COD removal capacities were 255 ,

$9200,2.8$ and $46 \%, 52 \%$ and $72 \%$ for biohydrogen, biogas and microbial fuel cell, respectively.

10 The outcomes suggested the prominence of biohydrogen process for simultaneous waste

11 treatment and energy recovery from LPW under the test conditions ensured.

12

13 Keywords: organic waste, anaerobic degradation, biogas, biohydrogen, microbial fuel cell 


\section{Introduction}

Nowadays, energy production and waste treatment are two crucial issues to maintain an adequate level of sustainable and environmental-safe technologies [1-3]. Among the various options to manage municipal garbage, deposition in landfills is the less attractive. Hence, applications of methods that utilize organic waste streams and simultaneously produce (renewable) energy are of particular interest and represent a hot research field currently. Biological approaches - being either aerobic or anaerobic - have been proven to efficiently manage various substances, including different fractions of municipal solid waste which is formed in remarkable quantities globally.

The North-Balaton Waste Treatment Plant (WTP) was opened recently in Királyszentistván, Hungary, which is one of the most up-to-date domestic solid waste treatment plants. It is able to receive $120000 \mathrm{t}_{\text {waste year }}^{-1}$ from 158 villages, cities nearby in Veszprém county. The processing steps of WTP are outlined in Fig. 1. First, the incoming wastes are mechanically treated. After shredding, iron is removed and the remaining parts are consecutively separated and sorted. As a result, an appropriate portion is sent for recycling, while others are subjected to further techniques [4].

Approximately, one third of the total annual waste is of organic origin and referred as the biofraction of municipal solid waste (BFMSW). It is drum-screened and exclusively treated aerobically by composting, which does not provide any benefits from energy point of view. However, BFMSW has notable energy potential. Therefore, in this study, it was aimed to test alternative ways of utilization that make energy recovery from BFMSW possible. In accordance with the interest of WTP, raw BFMSW has undergone pressing and a liquid fraction (liquid pressed waste - LPW) rich in organic compounds was obtained. Subsequently, LPW was employed as a substrate in our experiments (Fig. 2) for energy production in mature (biogas) as well as emerging (biohydrogen, microbial fuel cell) anaerobic degradation technologies.

Anaerobic digestion and concomitant biogas formation is an industrially recognized process [5-7], while biohydrogen is still an emerging energy carrier even though it has been studied for a long time [8-10]. Biogas and biohydrogen fermentations involve the microbiologically-assisted degradation of organic compounds and result in flammable gaseous energy carriers, which should be collected and purified [11-15]. In our earlier projects biogas 


\section{5}

$[16,17]$ as well as biohydrogen [18-22] production from various substrates have been investigated.

Microbial fuel cells (MFCs) are prosperous applications in the early-stage of research and gained remarkable attention from the scientific community in the last decade [23-25]. The MFC is a device that converts chemical energy into electricity through the biocatalytic activity of electrochemically active microorganisms. The classical MFC system consists of two main compartments: an anaerobic anode chamber and an air-sparged cathode compartment that are physically separated by a proton-exchange membrane (PEM). In appropriate conditions, biofilm can grow on the surface of the anode. Organic substances such as acetate, sugar or wastewater can be used as feedstock [26,27] in the microbial degradation process and as a result biomass, $\mathrm{CO}_{2}$, electrons and protons are produced. The electrons are delivered from the anode to the cathode through an external circuit, while protons move across the membrane to cathode to maintain electroneutrality. Oxygen supplied in the cathode chamber reacts with the protons and electrons to form water. The main process, which is crucial in terms of the electrical performance, is the transport of electrons from the cells to the anode surface. Therefore the properties and the surface area of the applied electrode material play an important role in the performance of the MFC [28]. In our former research, mesophilic anaerobic sludge was used as inocula in the MFCs seeking the operating stability and the effects of various substrates (monosaccharides, organic acids, industrial wastes) on system performance [26,27].

In this work, driven by the request of WTP, alternative routes for the BFMSW treatment were tested. Hence, LPW, a liquid derivative of BFMSW was provided by the WTP and applied as a novels starting material in three anaerobic technologies, namely biogas, biohydrogen and microbial fuel cell for energy extraction purposes. To our best knowledge, this is the first study on the applicability of LPW in the three contestant application mentioned. 


\section{Materials and methods}

\subsection{Substrate (LPW) and inoculum}

LPW, the liquid fraction of BFMSW gained by pressing, was used as a substrate in the experiments. The scheme of LPW production as well as the major LPW characteristics are presented by Fig. 2. Anaerobic sludge - taken from a domestic biogas plant operated in mesophilic conditions - with $30 \mathrm{~g} \mathrm{~L}^{-1}$ total COD value and $\mathrm{pH}$ of 7.8 was applied as seeding source.

\subsection{Biogas and biohydrogen experiments}

Experiments for biogas (Fig. 3) and biohydrogen (Fig. 4) production were carried out WTW OXITOP 100 manometric vessels having $500 \mathrm{~mL}$ total volume (Fig. 5). The reactors were filled with $50 \mathrm{~mL}$ substrate-sludge mixture in various ratios for biogas (Table 1) and in 1:1 ratio for biohydrogen (Table 2). The bioreactors were initially purged with high purity nitrogen (>99.9\%) to ensure fully anaerobic conditions. Subsequently, the vessels were closed by special manometric caps which were able to record the increasing pressure of the evolving gas in welldefined time intervals. The sealed bottles were incubated at $37{ }^{\circ} \mathrm{C}$ and $220 \mathrm{rpm}$ stirring rate was throughly applied using magnetic bar. The volume of the gas produced was calculated from the pressure data by using the ideal gas law. The given cumulative gas volumes in Table 1 and 2 are valid at $37{ }^{\circ} \mathrm{C}$ and 1 bar pressure. For the biohydrogen measurements, the initial $\mathrm{pH}$ values (Table 2) were adjusted by $\mathrm{HCl}$ solution and the mesophilic sludge was subjected to heatpretreatment $\left(75{ }^{\circ} \mathrm{C}, 45 \mathrm{~min}\right)$ to kill methanogenic organisms by adopting the method described in our previous research [21].

\subsection{Microbial fuel cells}

Dual-chamber MFCs were constructed (Fig. 6). Anode and cathode chambers had the same $60 \mathrm{~mL}$ capacity. Nafion 115 proton exchange membrane $\left(7 \mathrm{~cm}^{2}\right.$ surface area) was employed in between anode and cathode compartments. The anode and cathode electrodes 
possessed $25 \mathrm{~cm}^{2}$ surface areas and were made of carbon cloth. In the anode cell, using untreated mesophilic sludge was loaded $(60 \mathrm{~mL})$ as inoculum and anaerobic circumstances were provided, while the cathode side was filled with distilled water $(60 \mathrm{~mL})$ and continuously purged with air. The system was thermostated at $37^{\circ} \mathrm{C}$. The voltage generated was measured by using data logger (National Instruments USB-6008) and fixed $100 \Omega$ external resistors. The cells were started-up using the sludge only to develop electrochemically active anode-surface biofilm (first step in Fig. 7). Afterwards, the anode chamber was fed with the LPW and the collection of data was started (second step in Fig. 7) and initial COD values were measured (Table 3). Prior to the addition of LPW (Table 3), equal amount of anode-side solution was withdrawn to keep constant working volume.

\subsection{Analytical methods}

The gas compositions for biogas and biohydrogen were occasionally determined by Hewlett Packard 5890 gas chromatograph equipped with thermal conductivity detector (TCD). Capillary Carboplot ${ }^{\circledR}$ column was employed (Agilent Technologies, length: $60 \mathrm{~m}$, ID: $0.32 \mathrm{~mm}$, film thickness: $1.5 \mathrm{~mm}$ ) with $\mathrm{N}_{2}(99.9 \%)$ as carrier gas at a flow rate of $30 \mathrm{~mL} \mathrm{~min}^{-1}$. Split ratio of 50:1 was applied. The temperature of injector, column oven and detector was $130^{\circ} \mathrm{C}, 90{ }^{\circ} \mathrm{C}$ and $115{ }^{\circ} \mathrm{C}$, respectively. Chemical oxygen demand (COD) was followed according to standard methods [29]. The $\mathrm{pH}$ was measured by using a conventional $\mathrm{pH}$ glass electrode.

\subsection{Evaluation of experimental results}

The results presented throughout in this work are the mathematical averages of triplicates and the standard deviations were below $5 \%$. Energy yields $\left(\mathrm{J}_{\mathrm{E}}\right)$ (Table 4) were calculated by considering the gravimetric energy content of methane $\left(55.7 \mathrm{~kJ} \mathrm{~g}^{-1}\right)$ and hydrogen $\left(142 \mathrm{~kJ} \mathrm{~g}^{-1}\right)$ generated, the full operation times and the COD removed during the bioprocess. For MFCs, current $(I)$ data was computed according to Ohm's law in view of the voltage $(U)$ and the applied resistance $(R) . \mathrm{J}_{\mathrm{E}}$ for MFC was determined from voltage and current data, operating time and the COD eliminated. The cumulated energy (E) data for MFC can be estimated on the basis of power 
(from the voltage and current data) generated by integrating peak area (Fig. 7). This quantity shows the usable electrical energy (Table 3).

The efficiency of the treatments was characterized by $\mathrm{J}_{\mathrm{E}}$ and COD removal, which were calculated by Eq. 1 and Eq. 2:

$$
\mathrm{J}_{\mathrm{E}}=\mathrm{E} \Delta \mathrm{COD}^{-1} \mathrm{t}^{-1}
$$

$$
\text { COD removal }(\%)=100\left(\Delta \mathrm{COD} \mathrm{COD}_{0}^{-1}\right)
$$

where $\mathrm{E}$ is the produced energy in case of each processes, $\triangle \mathrm{COD}$ is the COD removed in the course of the experiments, $\mathrm{COD}_{0}$ is the initial total $\mathrm{COD}$ and $\mathrm{t}$ is the operation time.

\section{Results and discussion}

\subsection{Biogas production from $L P W$}

Since LPW had not been used in any microbial degradation process so far, experiences with its utilization were not available. Therefore, experiments were carried out applying various ratios of LPW and untreated sludge. It has turned out that high LPW/sludge ratios in the mixture should be avoided because the $\mathrm{pH}$ will drop to the acidic range that inhibits methanogenic organisms. Hence, initial LPW/sludge ratios were set to lower levels and it was found that the 1:1 ratio provided the highest cumulative methane formation $(424 \mathrm{~mL})$, as it can be observed in Table 1. The trends of biogas and methane evolution are illustrated in the progress curve (Fig. 3) for the case of using 1:1 LPW to sludge ratio. Besides gas production performance, the initial and final COD values are also listed in Table 1. It can be seen that biogas fermentation efficiency correlates well with COD removal since higher under high LPW/sludge ratio the low biogas yield $(65 \mathrm{~mL})$ was accompanied by low COD reduction $(14.4 \%)$. On the other hand, under optimal circumstances, quite good (52.3\%) COD removal could be attained where (Table 1).

Projecting the results with the literature is rather difficult due to the lack of studies with LPW substrate. Nevertheless, landfill leachate may be taken into account as a material which has more or less similar origin than LPW since it is also derived (at least in part) from solid wastes. 
Oz and Yarimtepe [30] investigated the utilization of raw landfill leachate $\left(28.5 \mathrm{~g} \mathrm{COD} \mathrm{L}^{-1}, 0.35\right.$ BOD $\left.\mathrm{COD}^{-1}\right)$ for biogas evolution in batch reactors under mesophilic temperature $\left(35^{\circ} \mathrm{C}\right)$ and $1.13 \mathrm{~L}_{\text {biogas }} \mathrm{L}^{-1} \mathrm{~d}^{-1}$ yield accompanied by $44 \%$ soluble COD reduction was achieved. These

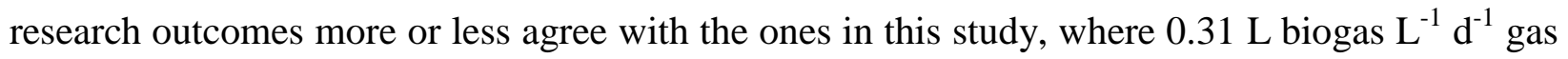
yields and 52.3\% COD removal efficiency could be reached. Furthermore, it was shown that (ultrasound) pretreatment of leachate can significantly enhance the anaerobic decomposition efficiency since it increases the soluble COD/total COD ratio and subsequently the amount of accessible substances for the bacteria [30]. Hence, this strategy may be equally useful for the management of LPW in the future. In another paper, Luo et al. [31] produced biogas from leachate of solid municipal waste demonstrating high-strength organic pollutant content (41-59 $\mathrm{g}$ $\left.\mathrm{COD} \mathrm{L}^{-1}\right)$ and good biodegradability (0.59-0.64 BOD COD $\left.{ }^{-1}\right)$, which are comparable with our LPW characteristics (111.6 $\left.\mathrm{g} \mathrm{COD} \mathrm{L}^{-1}, 0.45 \mathrm{BOD} \mathrm{COD}^{-1}\right)$. The measurements were conducted in continuous expanded granular sludge bed reactor at $35{ }^{\circ} \mathrm{C}$. The COD removal exceeded $80 \%$, while $6 \mathrm{~L}_{\mathrm{STP}}$ biogas $\mathrm{L}^{-1} \mathrm{~d}^{-1}$ yield was obtained under $15 \mathrm{~kg} \mathrm{COD} \mathrm{m}^{-3} \mathrm{~d}^{-1}$ organic loading rate and $3 \mathrm{~d}$ hydraulic retention time. In our batch system, $0.27 \mathrm{~L}_{\mathrm{STP}}$ biogas $\mathrm{L}^{-1} \mathrm{~d}^{-1}$ and $52.3 \%$ COD removal efficiency could be attained under $1.75 \mathrm{~kg} \mathrm{COD} \mathrm{m}^{-3} \mathrm{~d}^{-1}$ OLR (considering 40 days of fermentation and $3.5 \mathrm{~g}$ of total COD initially loaded to the batch bottles with $25 \mathrm{~mL}$ of LPW and 25 of $\mathrm{mL}$ sludge, as appears in Table 1). Presumably, the differences of the systems are accountable for the altered performances in terms of COD removal and biogas yield and suppose that continuous applications could be more productive and feasible to convert liquid landfill wastes into bioenergy carrier, methane.

\subsection{Biohydrogen evolution from LPW}

Pre-experiments were carried out to estimate the proper ratio for LPW and pretreated sludge. It was found that their equal portions (1:1) in the mixture are beneficial for our purpose (similarly to the biogas measurements). It is known that the initial $\mathrm{pH}$ can have a marked impact on biohydrogen formation process and acidic levels are favored by $\mathrm{H}_{2}$-producing strains [8]. Consequently, a wide range of $\mathrm{pH}$ (4.5-7.0) was screened to find the optimal value. The time profiles of the cumulated gas formations are depicted in Fig. 4, meanwhile other experimental results are summarized in Table 2. It can be seen in Fig. 4 that remarkable gas volumes were 
formed, except at $\mathrm{pH}=4.5$. The $\mathrm{H}_{2}$ content, however, was surprisingly low in the cases of $\mathrm{pH}$ 5.57.0 since vast majority of the gas was $\mathrm{CO}_{2}$. Nonetheless, even though a longer lag (adaption) phase was observed with $\mathrm{pH}=5.0$ finally it resulted in the highest gas volume produced (161 $\mathrm{mL}$ ), which contained high amount $(69.9 \%)$ of $\mathrm{H}_{2}$. Pertaining COD, as it can be extracted from Table 2, removal efficiency was lower than in case of biogas but it is still adequate. The best COD reduction (46.3\%) was coupled to the highest $\mathrm{H}_{2}$ production at $\mathrm{pH}$ of 5, which was assigned as the optimum value and should be applied in the further experiments.

Similarly to the case of biogas, comparison of results from LPW is attempted with landfill leachate. Liu et al. [32] optimized batch hydrogen generation from compost leachate and juice wastewater. As they concluded, initial $\mathrm{pH}$ of 5.5 was the most preferred by the $\mathrm{H}_{2-}$ producing cells at $35{ }^{\circ} \mathrm{C}$. These findings nicely confirm ours in this study with LPW, since optimum $\mathrm{pH}$ of 5 was identified at $37{ }^{\circ} \mathrm{C}$, where the highest $\mathrm{H}_{2}$ yield of $2.7 \mathrm{~mol} \mathrm{H}_{2} \mathrm{~kg}^{-1}$ $\mathrm{COD}_{\text {removed }}$ was attained. It was also demonstrated by Liu et al. [32] that the co-digestion of juice wastewater and compost leachate has led to a $28 \%$ increment $\left(2.06 \mathrm{~mol} \mathrm{H}_{2} \mathrm{~mol}^{-1}\right.$ glucose instead of $1.6 \mathrm{~mol} \mathrm{H}_{2} \mathrm{~mol}^{-1}$ glucose) in the hydrogen yield, which indicate well that liquid derivative of solid biodegradable waste can serve as a potential nutrient source. In contrast, Watanabe and Yoshino [33] conducted batch biohydrogen production research using landfill leachate derived from waste glass, waste plastics and construction waste. In their study, maximum biohydrogen yield (2.67 mol H $\mathrm{H}_{2} \mathrm{~mol}^{-1}$ carbohydrate added) could be reached at $\mathrm{pH}=7$ and $30{ }^{\circ} \mathrm{C}$. The disagreement of optimum can be attributed to unstandardized experimental conditions e.g. inocula origin and substrate composition. Nevertheless, the gas mixture formed in all cases was free of methane, even though the liquid waste substrates (leachates and LPW) were not treated before use to suppress possible methanogenic activity.

\subsection{Bioelectricity generation from LPW}

In this study five MFCs were operated in parallel with different LPW supplementation (Table 3). The data showed that the degradation of organic substances in the LPW and bioelectricity production took place in parallel. A typical voltage vs. time diagram is demonstrated in Fig. 7. 
MFCs can be characterized well in terms of substrate utilization by the calculation of the cumulated energy yield (Table 3) which ranged between 2.55 $\mathrm{J}$ and $18.25 \mathrm{~J}$ depending on the amount of LPW added. It can be pointed out that COD removal was excellent, mostly exceeding $80 \%$, which shows that MFCs are useful in wastewater treatment. Fig. 8 plots the cumulated energy vs. LPW COD input where a linear relationship could be observed between the two variables within the experimental borders. However, it should also be noted from Fig. 7 that higher doses of LPW demanded significantly more operating to be bioconverted, which can play a key role in process planning and changes the picture when calculating time-dependent energy yields.

In agreement with biogas and biohydrogen related section above, MFC performance from LPW is discussed comparatively with leachate. Leachate, as a landfill-originated liquid waste has been shown as a feasible starting material in microbial fuel cells that are able to sufficiently reduce the $\mathrm{COD}$ and $\mathrm{BOD}$ contents and simultaneously generate electricity. For example, Gálvez and co-workers [34] established a cascade system encompassing of 3 MFCs connected in series to treat leachate $\left(12.9 \mathrm{~g} \mathrm{COD} \mathrm{L}^{-1}, 0.49 \mathrm{BOD} \mathrm{COD}^{-1}\right)$ and reported $79.4 \% \mathrm{COD}$ removal efficiency in 4 days with continuous recirculation. Ganesh and Jambeck [35] designed MFCs where leachate was used not only as a substrate but also as an inoculum source. In their study, COD could be removed with a $75 \%$ efficiency using activated carbon anode in batch reactor, which is slightly lower than in this work from LPW (mostly >80\%). The current density reported $\left(114 \mathrm{~mA} \mathrm{~m}^{-2}\right)$ was fairly in par with our values ranging between $128-176 \mathrm{~mA} \mathrm{~m}^{-2}$. Tugtas et al. [36] used MFC to post-treat anaerobically pre-digested landfill leachate. In their study, stabilized current densities varied from 418 to $548 \mathrm{~mA} \mathrm{~m}^{-2}$ and $90 \%$ of the volatile fatty acids were removed in the course of 12 days batch operation. As it can be deducted, not only current densities but also COD elimination efficacies were higher than in this work (72-85\%). In addition, The MFC performances obtained by Tugtas et al. [36] were better in comparison with other literature studies applying untreated leachate and hence, it would appear that MFC could serve as promising auxiliary equipment for partially digested liquid-form landfill wastes. It is also to note that their MFC devices were continuously stirred which could have a notable contribution to the attractiveness of the system, since it facilitates the mass (nutrient) transfer between anodic biofilm and bulk phases. 


\subsection{Comparison of the processes}

The three processes can be compared on the basis of the products (regarding their energy content) generation in microbial fuel cell under optimal conditions. In Table 4, the performances of biogas, biohydrogen fermentation and bioelectricity are shown. For comparison purposes, maximum energy yields $\left(\mathrm{J} \mathrm{g}^{-1} \Delta \mathrm{COD} \mathrm{d} \mathrm{d}^{-1}\right)$ and respective COD removal efficiencies were chosen as primarily process indicators.

Regardless of the technology, it can be seen that COD elimination capacities were found rather comparable. However, MFC provided the best one with $71.6 \%$, followed by biomethane $(52.3 \%)$ and biohydrogen $(46.3 \%)$. Considering $\mathrm{J}_{\mathrm{E}}$, it has turned out that biohydrogen took the

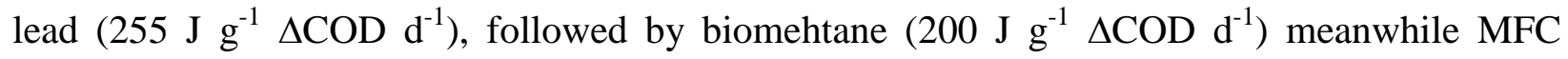
remained order of magnitude behind them with $2.8 \mathrm{~J} \mathrm{~g}^{-1} \Delta \mathrm{COD} \mathrm{d}^{-1}$.

\section{Conclusions}

Three anaerobic degradation processes were applied to test a new substrate, the liquid fraction of BFMSW (LPW) for biogas, biohydrogen formation and for power generation in microbial fuel cells. Successful experiments were carried out in all the processes, the unconventional substrate - rich in organic substances - was microbiologically transformed into methane, hydrogen and power. It has turned out that all the processes degraded the waste effectively, the COD removal efficiencies for MFC measurements exceeded even $70 \%$, while in case of biogas and biohydrogen it was found below. Biogas formation provided the highest energy output, but the highest energy yield (energy value normalized by the COD degradation value and operating time) was found in case of biohydrogen production. Thus, from the energy point of view, biohydrogen seems the most promising way to obtain energy from the particular waste material, LPW.

In the future, measurements will be continued with all the three processes to further optimize the bioprocess conditions before final recommendation since not only energy, but other aspects can be taken into account e.g. reliability of the process, pre- or post-treatment is necessary or not. For example, the gaseous energy carriers $\left(\mathrm{CH}_{4}\right.$ or $\left.\mathrm{H}_{2}\right)$ needs a transformation step for utilization (e.g. combustion of methane in a co-generation process, oxidation of 
1 hydrogen in a PEMFC with preliminary gas purification), while MFCs provide directly electric

2 energy. As a result, combined applications (i.e. biohydrogen integrated with MFC) might be

3 better solutions. In addition, the energy investment of waste processing to obtain LPW should

4 also be considered when selecting the most feasible technology for the management of municipal

5 solid waste. It is likely that the final system should involve the treatment of residual solid waste

6 (secondary product of pressing LPW substrate). For this purpose, anaerobic-phased solids

7 digesters could be good candidates to produce additional biogas and compensate the energy

8 consumption of pressing [37].

9

10 Acknowledgements

11

12 This work was supported by the European Union and co-financed by the European Social

13 Fund in the frame of the TAMOP-4.2.2.A-11/1/KONV-2012-0071 and TAMOP-4.2.2/A-

14 11/1/KONV-2012-0038 projects. Nándor Nemestóthy acknowledges the János Bolyai Research

15 Scholarship of the Hungarian Academy of Sciences.

16

17 


\section{References}

[1] Fino, D., Conti, E., Martini, R., Conti, R.: Future Perspectives for Bio-Energy Production in the Province of Turin. Waste Biomass Valor. 2, 59-64 (2011)

[2] Savva, P.G., Costa, C.N., Charalambides, A.G.: Environmental, Economical and Marketing Aspetcs of the Operation of a Waste-to-Energy Plant in the Kotsiatis Landfill in Cyprus. Waste Biomass Valor. 4, 259-269 (2013)

[3] Zis, T., Bell, M.G.H., Tolis, A., Aravossis, K.: Economic Evaluation of Alternative Options for Municipal Solid Waste Management in Remote Locations. Waste Biomass Valor. 4, 287-296 (2013)

[4] Sarkady, A., Kurdi, R., Rédey, A.: RDF - Refuse derived fuel, possibilities in the NorthBalaton Regional waste management system. Pollack Periodica. 9, 23-30 (2014)

[5] Gerardi, H.M.: The microbiology of anaerobic digesters, John Wiley \& Sons, Hoboken, New Jersey (2003)

[6] Mata-Alvarez, J., Macé, S., Llabrés, P.: Anaerobic digestion of organic solid wastes. An overview of research achivements and perspectives. Bioresour. Technol. 74, 3-16 (2000)

[7] Speece, R.E.: Anaerobic biotechnology for industrial wastewaters, Archae Press, Tennessee, USA (1996)

[8] Bakonyi, P., Nemestóthy, N., Simon, V., Bélafi-Bakó, K.: Review on the start-up experiences of continuous fermentive hydrogen producing bioreactors. Renew. Sust. Energ. Rev. 40, 806-813 (2014)

[9] Bakonyi, P., Nemestóthy, N., Simon, V., Bélafi-Bakó, K.: Fermentative hydrogen production in anaerobic membrane bioreactors: A review. Bioresour. Technol. 156, 357-363 (2014)

[10] Kumar, G., Bakonyi, P., Periyasamy, S., Kim, S.H., Nemestóthy, N., Bélafi-Bakó, K.: Lignocellulose biohydrogen: practical challenges and recent progress. Renew. Sust. Energ. Rev. (2015). http://dx.doi.org/10.1016/j.rser.2015.01.042 
[11] Bakonyi, P., Nemestóthy, N., Bélafi-Bakó, K.: Biohydrogen purification by membranes: An overview on the operational conditions affecting the performance of non-porous, polymeric and ionic liquid based gas separation membranes. Int. J. Hydrogen Energ. 38, 9673-9687 (2013)

[12] Bakonyi, P., Kumar, G., Nemestóthy, N., Lin, C.Y., Bélafi-Bakó, K.: Biohydrogen purification using a commercial polyimide membrane module: studying the effects of some process variables. Int. J. Hydrogen Energ. 38, 15092-15099 (2013)

[13] Ramírez-Morales, J.E., Tapia-Venegas, E., Nemestóthy, N., Bakonyi, P., Bélafi-Bakó, K., Ruiz-Filippi, G.: Evaluation of two gas membrane modules for fermentative hydrogen separation. Int. J. Hydrogen Energ. 38, 14042-14052 (2013)

[14] Bauer, F., Persson, T., Hulteberg, C., Tamm, D.: Biogas upgrading - technology overview, comparison and perspectives for the future. Biofuels Bioprod. Biorefin. 7, 499-511 (2013)

[15] Chmielewski, A.G., Urbaniak, A., Wawryniuk, K.: Membrane enrichment of biogas from two-stage pilot plant using agricultural waste as a substrate. Biomass Bioenergy 58, 219-228 (2013)

[16] Szentgyörgyi, E., Nemestóthy, N., Bélafi-Bakó, K.: Anaerobic moving bed biofilm fermenter for biogas production. Env. Prot. Eng. 36, 117-125 (2010)

[17] Szentgyörgyi, E., Nemestóthy, N., Bélafi-Bakó, K.: Application of membranes in biogas production. Desalin. Water Treat. 14, 112-115 (2010)

[18] Bélafi-Bakó, K., Búcsú, D., Pientka, Z., Bálint, B., Herbel Z., Kovács, K.L., Wessling, M.: Integration of biohydrogen fermentation and gas separation processes to recover and enrich hydrogen. Int. J. Hydrogen Energ. 31, 1490-1495 (2006)

[19] Bakonyi, P., Nemestóthy, N., Lövitusz, É., Bélafi-Bakó, K..: Application of PlackettBurman experimental design to optimize biohydrogen fermentation by $E$. coli (XL1-BLUE). Int. J. Hydrogen Energ. 36, 13949-13954 (2011)

[20] Bakonyi, P., Nemestóthy, N., Ramirez, J., Ruiz-Filippi, G., Bélafi-Bakó, K.: E. coli (XL1BLUE) for continuous fermentation of $\mathrm{bioH}_{2}$ and its separation by polyimide membrane. Int. J. Hydrogen Energ. 37, 5623-5630 (2012) 
[21] Bakonyi, P., Borza, B., Orlovits, K., Simon, V., Nemestóthy, N., Bélafi-Bakó, K.: Fermentative hydrogen production by conventionally and unconventionally heat pretreated seed cultures: a comparative assessment. Int. J. Hydrogen Energ. 39, 5589-5596 (2014)

[22] Bakonyi, P., Nemestóthy, N., Lankó, J., Rivera, I., Buitrón, G., Bélafi-Bakó, K.: Simultaneous biohydrogen production and purification in a double-membrane bioreactor system. Int. J. Hydrogen Energ. 40, 1690-1697 (2015)

[23] Logan, B.E.: Microbial fuel cells. John Wiley \& Sons, New York (2008)

[24] Logan, B.E., Hamelers, B., Rozendal, R., Schröder, U., Keller, J., Freguia, S., Aelterman, P., Verstraete, W., Rabaey, K.: Microbial fuel cells: methodology and technology. Environ. Sci. Technol. 40, 5181-5192 (2006)

[25] Lovley, D.R.: Microbial fuel cells: novel microbial physiologies and engineering approaches. Curr. Opin. Biotechnol. 17, 327-332 (2006)

[26] Bélafi-Bakó, K., Vajda, B., Nemestóthy, N.: Study on operation of a microbial fuel cell using mesophilic anaerobic sludge. Desalin. Water Treat. 35, 222-226 (2011)

[27] Vajda, B., Nemestóthy, N., Bakonyi, P., Belafi-Bakó, K.: Xylose substrate as the only nutrient in the operation of microbial fuel cells. Env. Prot. Eng. 40, 132-141 (2014)

[28] Wei, J., Liang, P., Huang, X.: Recent progress in electrodes for microbial fuel cells. Bioresour. Technol. 102, 9335-9344 (2011)

[29] APHA, 1995. Standard methods for the examination of water and wastewater. $19^{\text {th }}$ ed. New York, USA: American Public Health Association.

[30] Oz, N.A., Yarimtepe, C.C.: Ultrasound assisted biogas production from landfill leachate. Waste Manage. 34, 1165-1170 (2014)

[31] Luo, J., Lu, X., Liu, J., Qian, G., Lu, Y.: Biogas recirculation for simultaneous calcium removal and biogas purification within an expanded granular sludge bed system treating leachate. Bioresour. Technol. 173, 317-323 (2014)

[32] Liu, Q., Zhang, X., Zhou, Y., Zhao, A., Chen, S., Qian, G., Xu, Z.P.: Optimization of fermentative biohydrogen production by response surface methodology using fresh leachate as nutrient supplement. Bioresour. Technol. 102, 8661-8668 (2011) 
1 [33] Watanabe, H., Yoshino, H.: Biohydrogen using leachate from an industrial waste landfill as

2 inoculum. Renew. Energ. 35, 921-924 (2010)

3 [34] Gálvez A, Greenman J, Ieropoulos I. Landfill leachate treatment with microbial fuel cells;

4 scale-up through plurality. Bioresour. Technol. 100, 5085-5091 (2009)

5 [35] Ganesh, K., Jambeck, J.R.: Treatment of landfill leachate using microbial fuel cells:

6 Alternative anodes and semi-continuous operation. Bioresour. Technol. 139, 383-387 (2013)

7 [36] Tugtas, A.E., Cavdar, P., Calli, B.: Bio-electrochemical post-treatment of anaerobically

8 treated landfill leachate. Bioresour. Technol. 139, 266-272 (2013)

9 [37] Zhu, B., Zhang, R., Gikas, P., Rapport, J., Jenkins, B., Li., X.: Biogas production from 10 municipal solid wastes using an integrated rotary drum and anaerobic-phased solids digester 11 system. Bioresour. Technol. 101, 6374-6380 (2010) 


\section{List of tables and figures}

2

4

Table 1 - Results of the biogas experiments

Table 2 - Results of the biohydrogen experiments

Table 3 - Experimental and calculated results of the MFC measurements

Table 4 - Comparison of energy yields and COD removal efficiencies

Fig. 1 - Scheme of the processes in the waste treatment plant

Fig. 2 - LPW production and characteristics

Fig. 3 - Biogas and biomethane formation as a function of time for 1:1 LPW to sludge ratio Biogas: triangle; Methane: square

Fig. 4 - Gas formation curves of the biohydrogen experiments dark blue: $\mathrm{pH}=7$; red: $\mathrm{pH}=4.5$; green: $\mathrm{pH}=5$; purple: $\mathrm{pH}=5.5$; light blue: $\mathrm{pH}=6$; orange: $\mathrm{pH}=6.5$

Fig. 5 - The experimental set-up for biogas and biohydrogen production 1 - manometric cap; 2: septum for gas sampling

Fig. 6 - Illustration of the dual chamber MFC

Fig. 7 - Effect of substrate (9 mL LPW) feeding on voltage output. 1: Inoculation 2: Substrate (LPW) addition. (t represents the time interval that was considered for energy yield calculation)

Fig. 8 - Cumulated energy output as a linear function of COD input $\left(\mathrm{R}^{2}=0.989\right)$ and required operation time for the various cases (dotted line) 
Table 1

\begin{tabular}{ccccccc}
$\begin{array}{c}\text { LPW } \\
(\mathrm{mL})\end{array}$ & $\begin{array}{c}\text { Sludge } \\
(\mathrm{mL})\end{array}$ & $\mathrm{COD}^{*}{ }_{\text {in }}$ & $\mathrm{COD}^{*}{ }_{\mathrm{f}}$ & $\begin{array}{c}\text { COD removal } \\
(\%)\end{array}$ & $\begin{array}{c}\text { Biogas } \\
(\mathrm{mL})\end{array}$ & $\begin{array}{c}\text { Methane } \\
(\mathrm{mL})\end{array}$ \\
\hline 15 & 35 & 2.7 & 1.18 & 56.5 & 515 & 355 \\
25 & 25 & 3.5 & 1.65 & 52.3 & 622 & 424 \\
35 & 15 & 4.4 & 3.7 & 14.4 & 369 & 65 \\
\hline
\end{tabular}

*: initial $\left(\mathrm{COD}_{\text {in }}\right)$ and final $\left(\mathrm{COD}_{\mathrm{f}}\right) \mathrm{COD}$ values are in $\left[\mathrm{g} \mathrm{COD} 50 \mathrm{~mL}^{-1}\right.$ mixture] unit 
Table 2

\begin{tabular}{ccccccc} 
Initial pH & $\mathrm{COD}^{*}{ }_{\text {in }}$ & $\mathrm{COD}_{\mathrm{f}}{ }_{\mathrm{f}}$ & $\begin{array}{c}\mathrm{COD} \\
\text { removal } \\
(\%)\end{array}$ & $\begin{array}{c}\mathrm{Gas} \\
\text { formed } \\
(\mathrm{mL})\end{array}$ & $\mathrm{H}_{2}(\%)$ & $\mathrm{CO}_{2}(\%)$ \\
\hline 4.5 & & 3.02 & 13.7 & 22 & 66.5 & 33.5 \\
5 & & 1.88 & 46.3 & 161 & 69.9 & 30.1 \\
5.5 & 3.5 & 2.18 & 37.7 & 149 & 11.3 & 88.7 \\
6 & & 2.27 & 35.1 & 132 & 9 & 91 \\
6.5 & & 2.61 & 25.4 & 122 & 8 & 92 \\
7 & 2.39 & 31.7 & 138 & 7 & 93 \\
\hline
\end{tabular}

*: initial $\left(\mathrm{COD}_{\text {in }}\right)$ and final $\left(\mathrm{COD}_{\mathrm{f}}\right) \mathrm{COD}$ values are in $\left[\mathrm{g} \mathrm{COD} 50 \mathrm{~mL}^{-1}\right.$ mixture] unit

2 
Table 3

\begin{tabular}{cccccccc}
$\begin{array}{c}\text { LPW feed } \\
(\mathrm{mL})\end{array}$ & COD*$^{*}{ }_{\mathrm{in}}$ & $\mathrm{COD}_{\mathrm{f}}^{*}$ & $\begin{array}{c}\mathrm{COD} \\
\text { removal } \\
(\%)\end{array}$ & $\begin{array}{c}\text { Current } \\
\text { density } \\
\left(\mathrm{mA} \mathrm{m}^{-2}\right)\end{array}$ & $\begin{array}{c}\text { Operation } \\
\text { time }(\mathrm{d})\end{array}$ & $\begin{array}{c}\text { Cumulated } \\
\text { energy }(\mathrm{J})\end{array}$ & $\mathrm{J}_{\mathrm{E}}\left(\mathrm{J} \mathrm{g}^{-1} \Delta \mathrm{COD} \mathrm{d}^{-1}\right)$ \\
\hline 1 & 0.36 & 0.1 & 72.2 & 160 & 3.5 & 2.55 & 2.80 \\
3 & 0.64 & 0.11 & 82.8 & 128 & 12 & 6.32 & 0.99 \\
5 & 1.07 & 0.2 & 81.3 & 140 & 14.5 & 10.71 & 0.85 \\
7 & 0.92 & 0.18 & 80.4 & 152 & 15.5 & 15.93 & 1.39 \\
9 & 1.29 & 0.26 & 79.8 & 176 & 16 & 18.25 & 1.11 \\
\hline
\end{tabular}

*: initial $\left(\mathrm{COD}_{\text {in }}\right)$ and final $\left(\mathrm{COD}_{\mathrm{f}}\right) \mathrm{COD}$ values are in $\left[\mathrm{g} \mathrm{COD} 60 \mathrm{~mL}^{-1}\right.$ mixture] unit 
Table 4

\begin{tabular}{|c|c|c|c|}
\hline & $\mathrm{BioCH}_{4}$ & $\mathrm{BioH}_{2}$ & MFC \\
\hline Energy obtained $(\mathrm{J})$ & 14611 & 1240 & 2.55 \\
\hline Time period (d) & 40 & 3 & 3.5 \\
\hline COD removal (\%) & 52.3 & 46.3 & 72.2 \\
\hline $\mathrm{J}_{\mathrm{E}}\left(\mathrm{J} \mathrm{g}^{-1} \Delta \mathrm{COD} \mathrm{d}^{-1}\right)$ & 200 & 255 & 2.8 \\
\hline
\end{tabular}

2 
Fig. 1

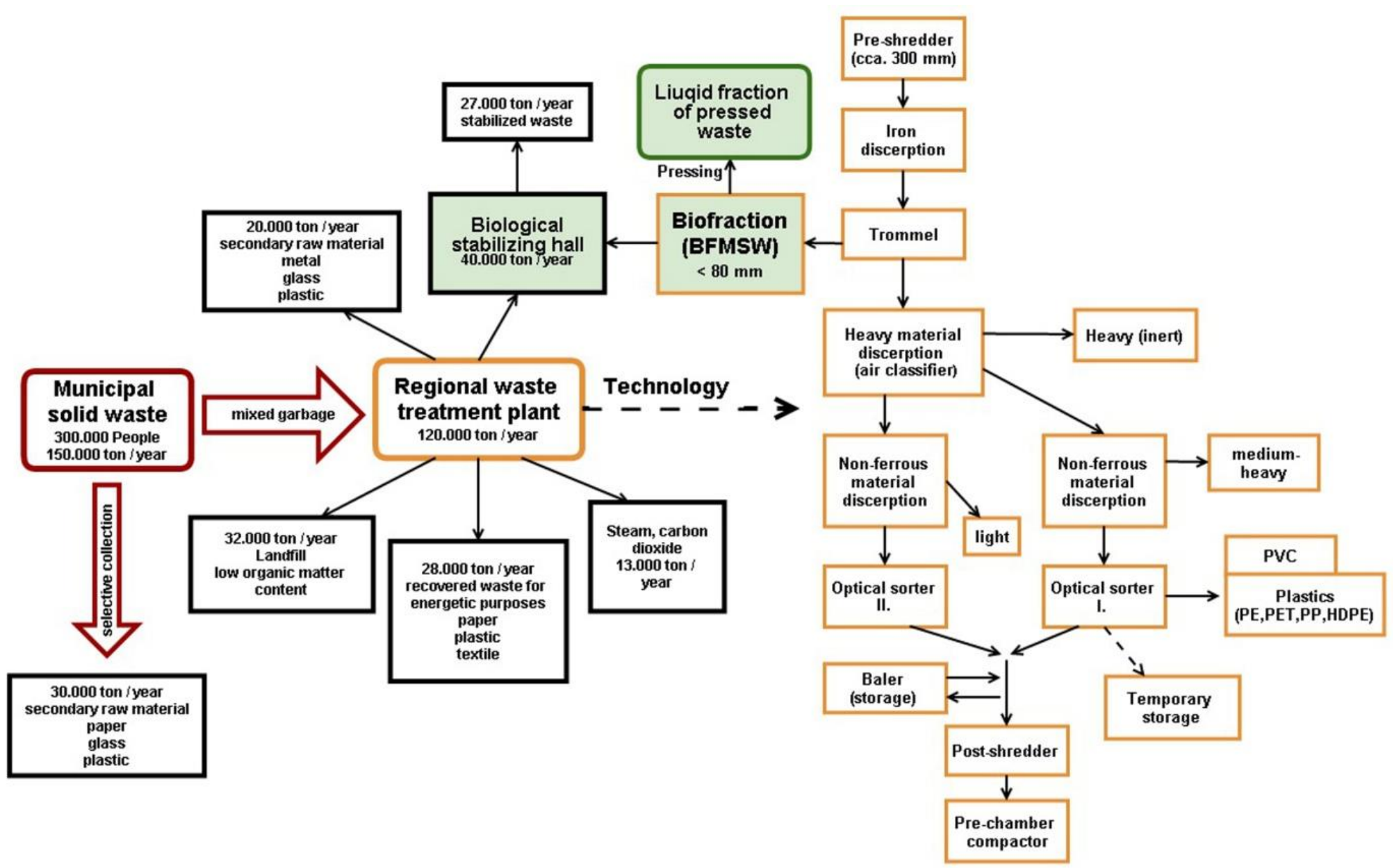


Fig. 2

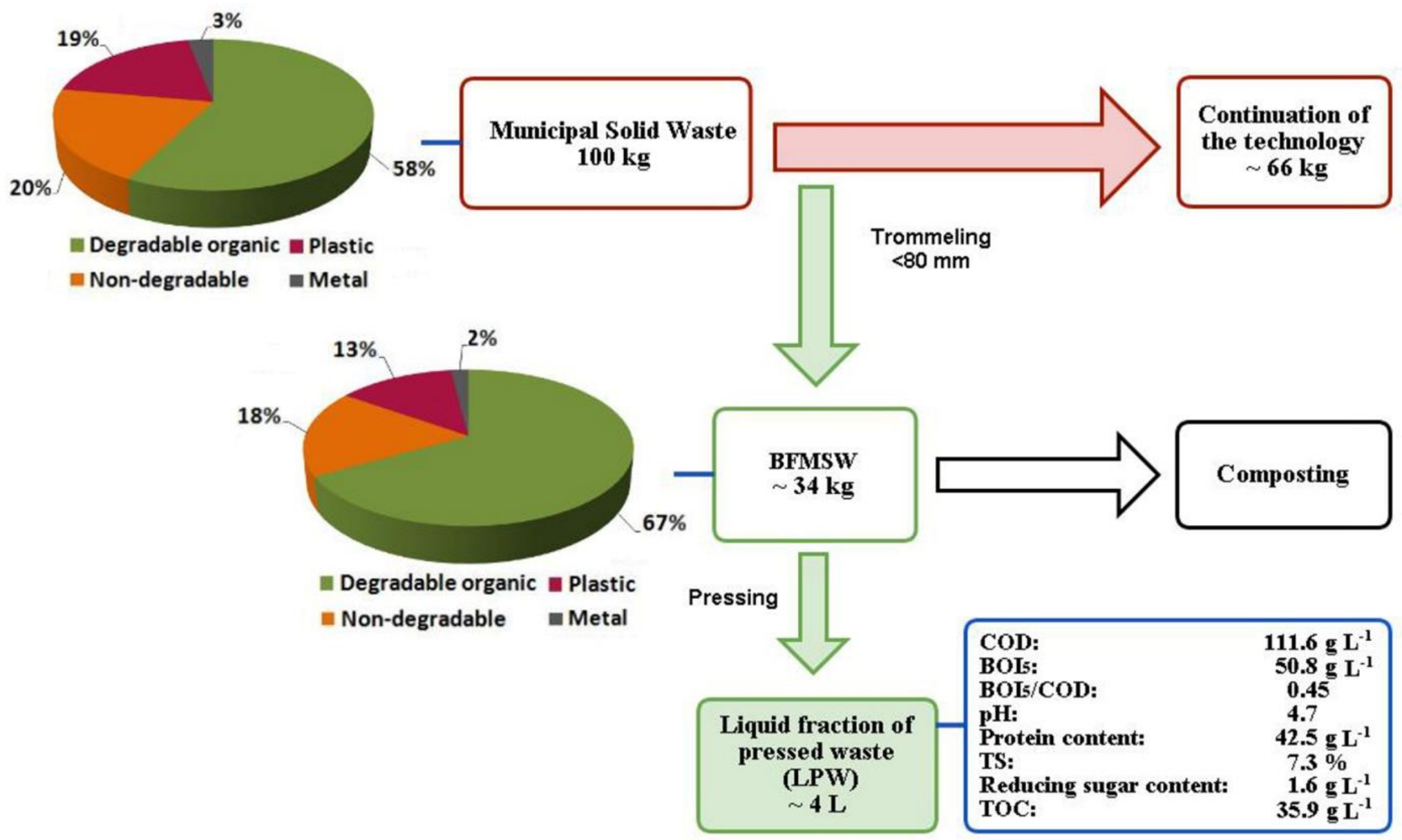


Fig. 3

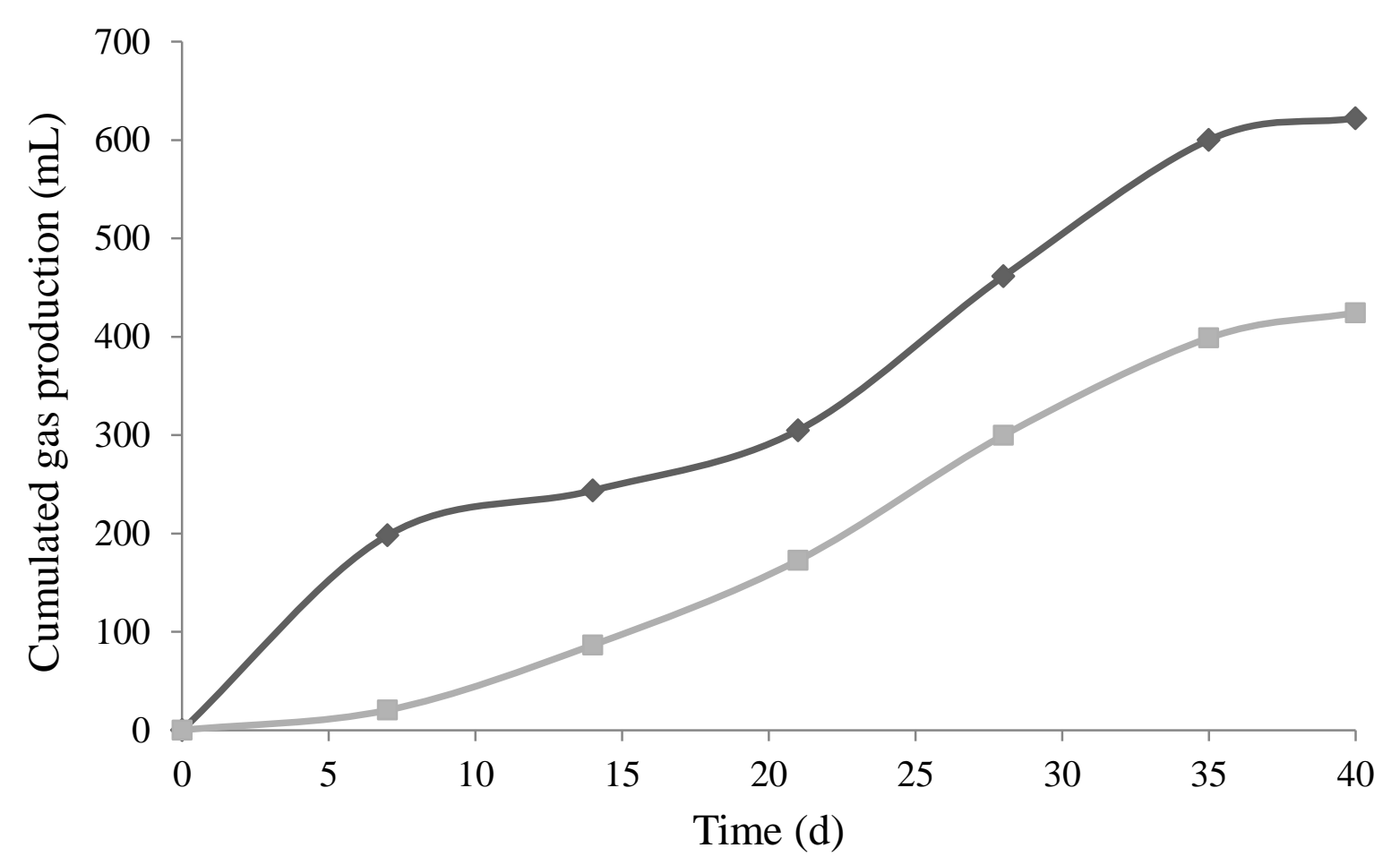


Fig. 4

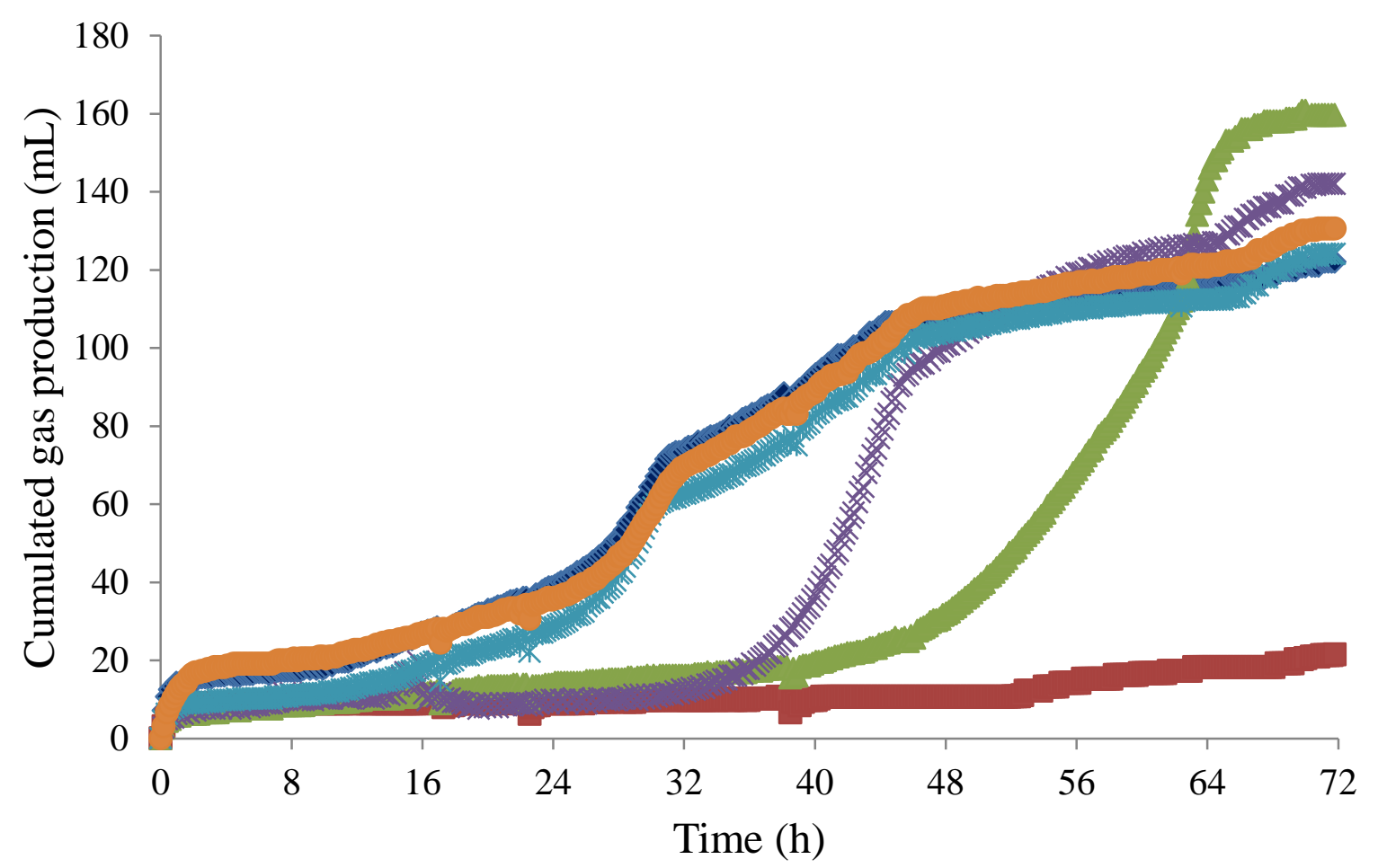


Fig. 5

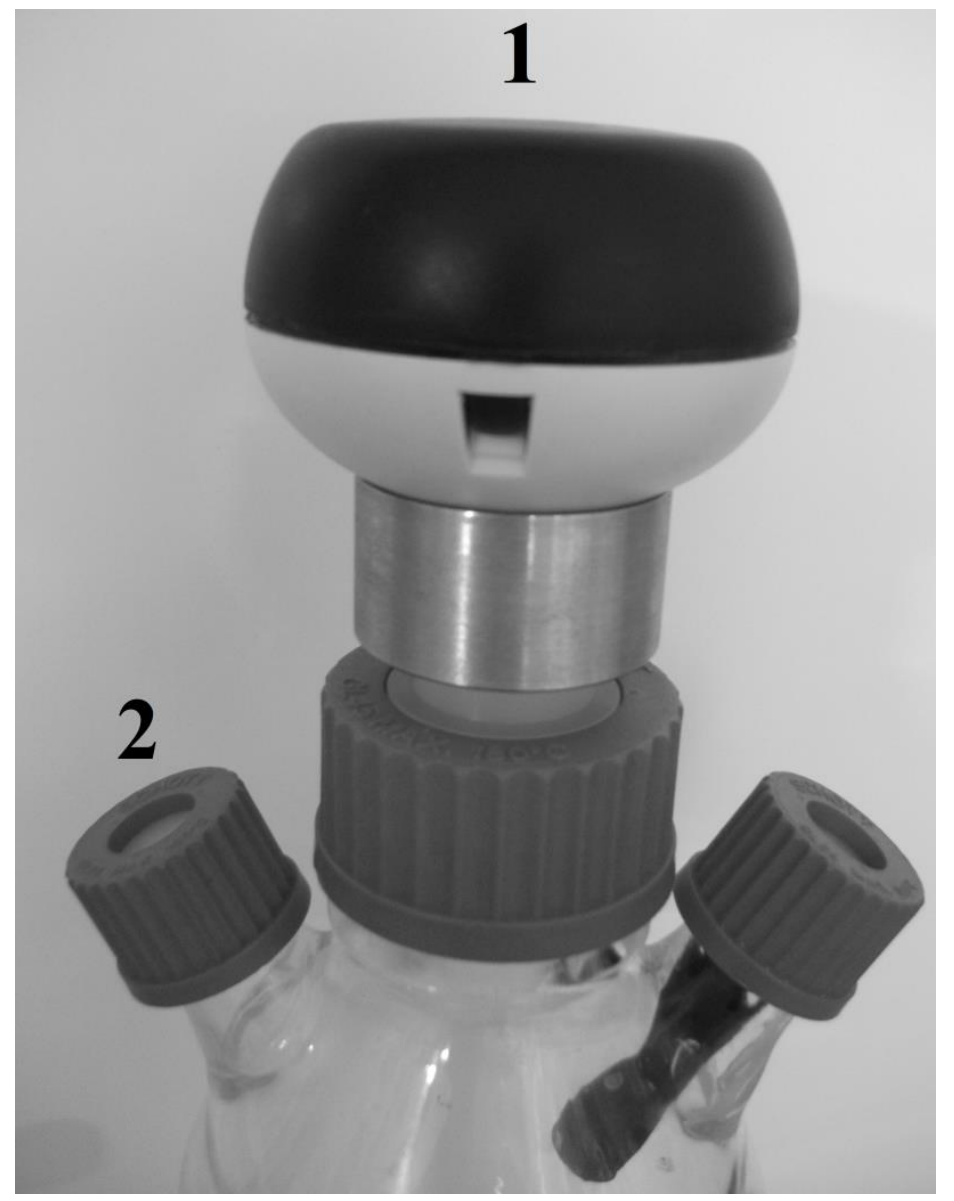


Fig. 6

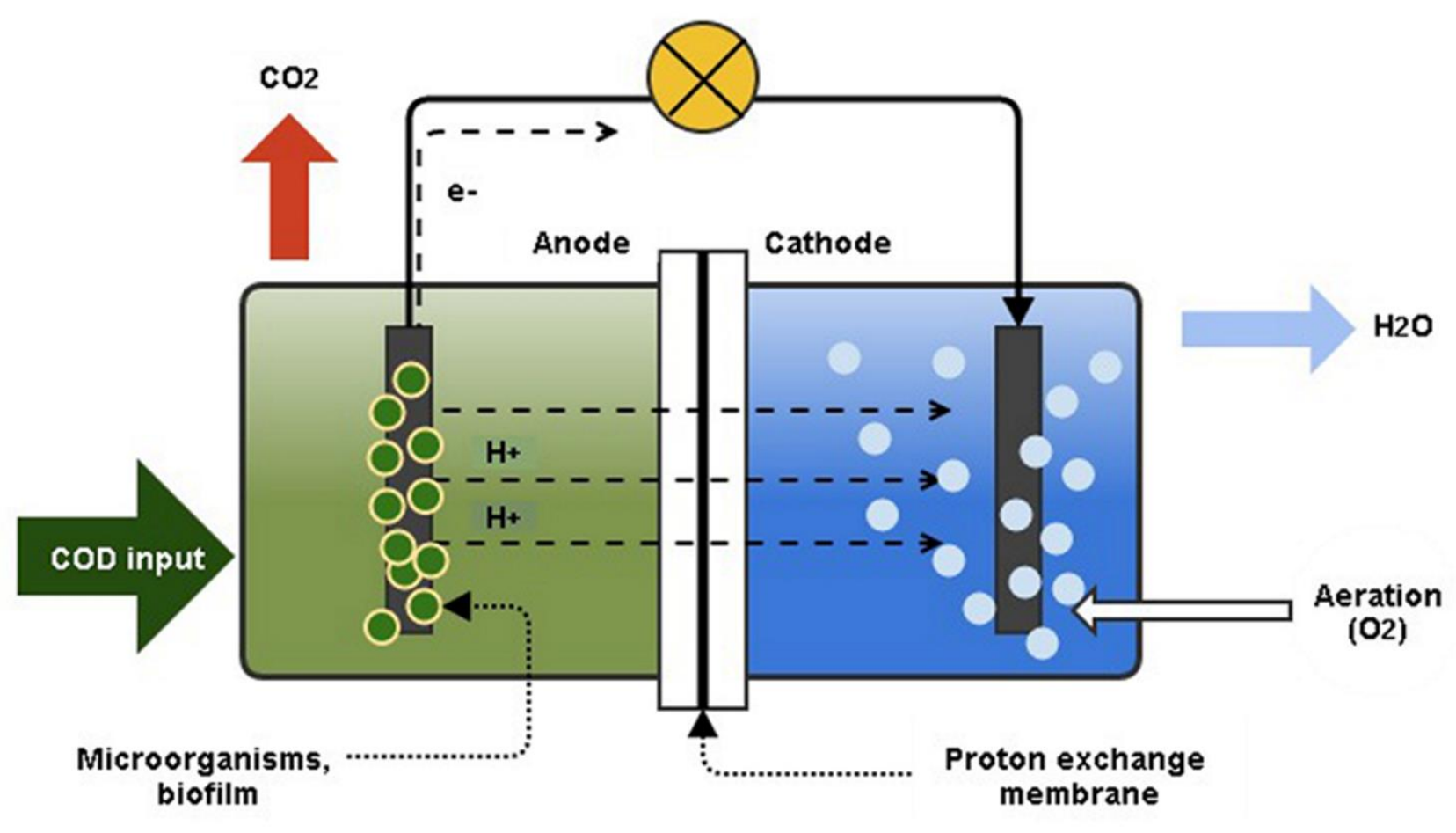


Fig. 7

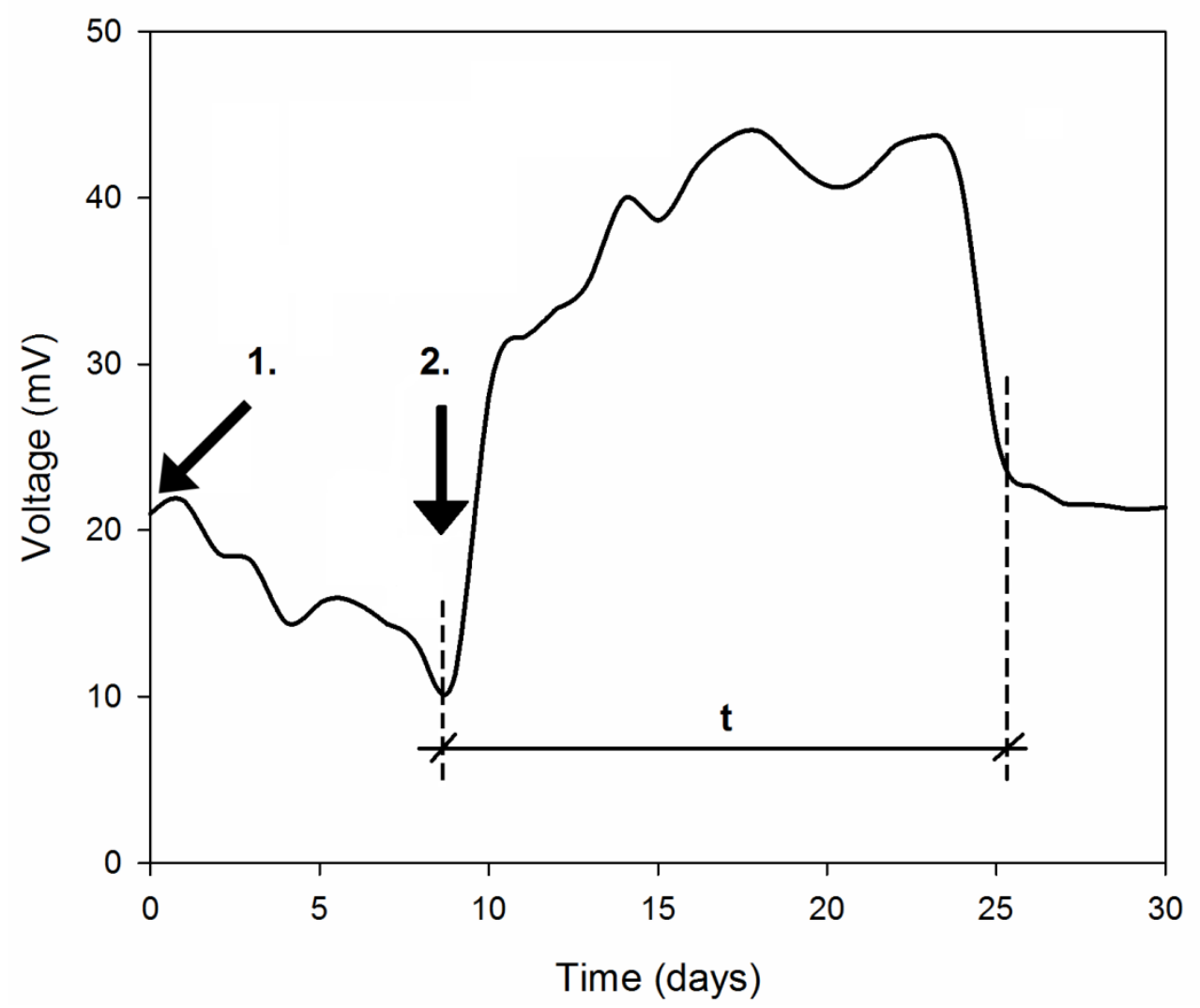


Fig. 8

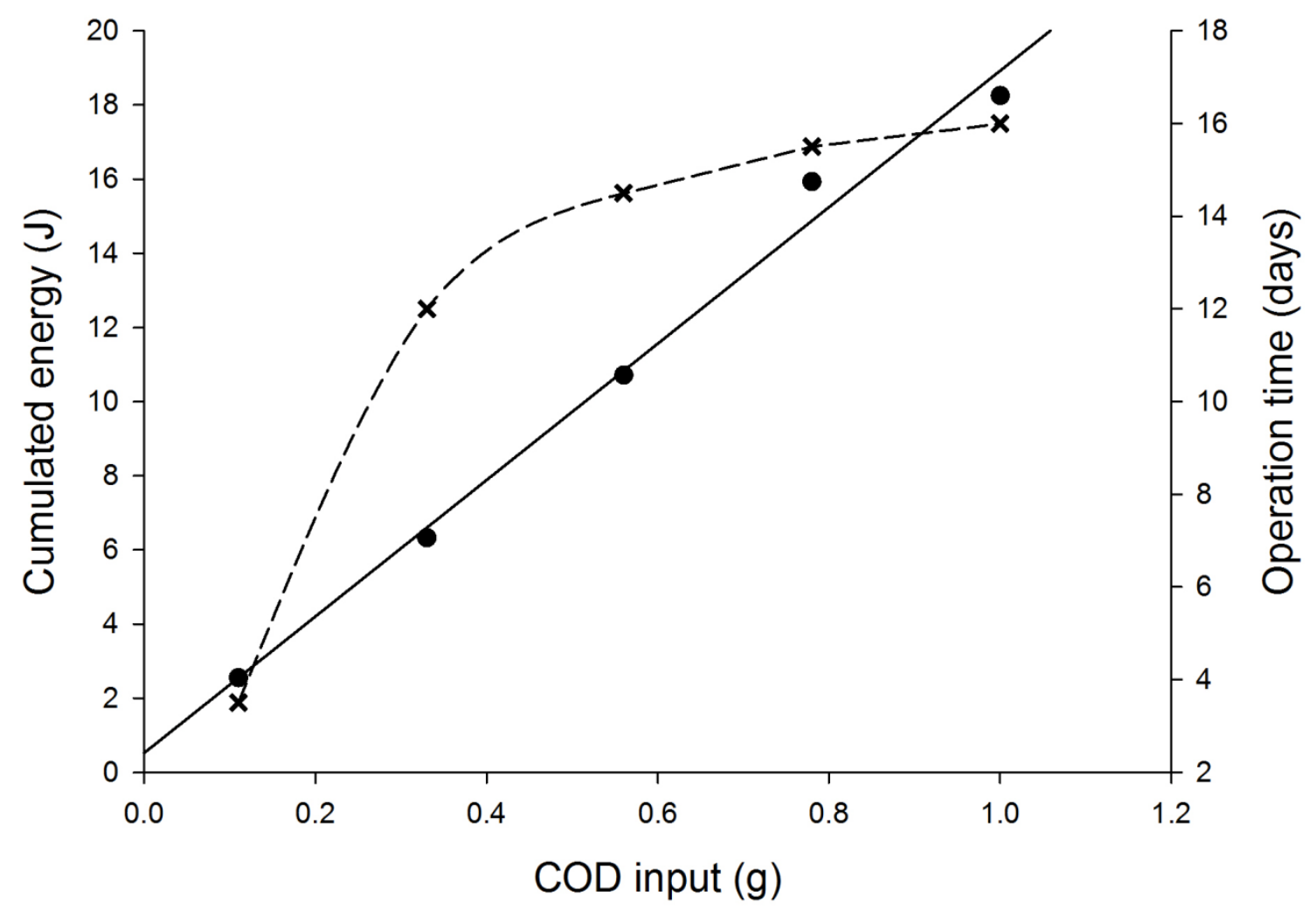

